\title{
Discourse Innovation of Ideological and Political Education under the View of Culture \\ Yi Zhang ${ }^{1, a}$, Huahua Cui ${ }^{1, b}$ \\ ${ }^{1}$ School of humanities,economics and law, Northwestern Polytechnical University, Xi'an 710129, China \\ a zhangyi.2000@163.com , b cuihua52@nwpu.edu.cn
}

Keywords: ideological and political education discourse; cultural confusion; cultural innovation

\begin{abstract}
The discourse of ideological and political education, as a special speech symbol system which can be constructed and developed on the basis of specific culture, is also an important cultural phenomenon. Based on the times context of modern transformation of ideological and political education discourse, the author considers from the perspective of culture and shows modern cultural confusions, including the vagueness of modern construction of ideological and political education discourse culture pedigrees, the weakness of local absorption of ideological and political education discourse culture resources and the complexity of rational identification of ideological and political education discourse culture patterns. In order to achieve cultural innovation of ideological and political education discourse in the context of modernity, modern cultural confidence of ideological and political education discourse needs to be actively formed, modern cultural inheritance of ideological and political education discourse needs to be rationally promoted, and modern cultural context of ideological and political education discourse needs to be scientifically constructed.
\end{abstract}

\section{Introduction}

Discourse is related to culture, which means that "language expresses and carries and symbolizes cultural reality, the two can not be separated"[1]. Ideological and political education discourse is an important education carrier and hand grab that advances pragmaticality and effectiveness of ideological and political education to the position of core. The core intention of discourse is to achieve the free and comprehensive development of the educated. "Each progress in culture is one step towards freedom"[2]. In the context of modernity, in the new cultural pattern with globalized cultural transmission and multiple cultural representation and diversified cultural patterns, cultural confusion of ideological and political education discourse is gradually prominent. Whether we can rationally interpret current cultural dilemma of ideological and political education discourse and scientifically think about the cultural patterns of ideological and political education discourse in the context of modernity or not, is related to the effectiveness of modern transformation of ideological and political education discourse and the effectiveness of ideological and political education and the improvement of the effectiveness.

\section{Cultural Interpretation of Ideological and Political Education Discourse}

Ideological and political education discourse practice as a cultural phenomenon, is strongly related to culture. On the one hand, with regard to essence, the ideological and political education discourse, as an important component of social culture, has always existed in a specific cultural situation, the innovation and development of the discourse of ideological and political education continue to drive the social and cultural advancement; on the other hand, the specific cultural ecology, cultural resources and cultural environment created conditions for the modern transformation of ideological and political education discourse in the aspects of objective, content and ways and became the important support that guides and coordinates and integrates ideological and political education discourse. Generally speaking, the discourse of ideological and political 
education and culture have certain consistency and relevance. The generation and change of culture can not be separated from the innovation and transformation of the discourse of ideological and political education. If it departs from the development of ideological and political education discourse, inheritance and innovation of culture will suffer a major block; at the same time, the creation of ideological and political education discourse, the acquisition of pragmaticality and effectiveness also requires a strong driving force of culture. If ideological and political education discourse leaves the nourishment and education of culture, it will be like wood without root and like water without source, the development of itself will be greatly limited.

\section{Cultural Confusion Interpretation of Ideological and Political Education Discourse}

\subsection{Tradition and Modernity: the Vagueness of Modern Construction of Ideological and Political Education Discourse Culture Pedigrees}

In the profound transformation of social structure, content and mode characterized by modern transformation, a large number of the educated people are living in the new society of ideological and political education discourse with diversified cultural surging, networked stereoscopic interaction, digital information extraction and equal discourse control. They face the fusion and collision between traditional cultural discourse and modern cultural discourse, positive cultural discourse and reverse cultural discourse, advanced cultural discourse and backward cultural discourse, which is based on the different and complex ideas of cultural pedigree construction of ideological and political education discourse. On the one hand, the educated people are confined to their own ideological and behavioral characteristics and tend to generate the ideological framework and cultural concept system with multiple value and diversified content and abundant connotation. On the other hand, under the influence of modern multicultural discourse pattern, the educated people profoundly reflect the legitimacy and rationality of inherent traditional cultural discourse pattern and its inherent cultural values and significance, resulting in a certain degree of questioning and wandering mentality.

\subsection{Continuance and Breakage: the Weakness of Local Absorption of Ideological and Political Education Discourse Culture Resources}

The majority of the educated people's ideological level is subject to irrational cultural discourse such as allopatry, negativity, venting, and so on. So that it's easy for them to produce a set of deviations in the understanding level in the process of interaction with the society, such as avoiding lofty ideals, neglecting ideals, wearing volition, calculating and being extremely selfish. They may produce negative ideas such as "cultural nothingness" and "faith nothingness". The author reflects the current discourse practice of ideological and political education, and stands on the political nature, class character and ideology of ideological and political education discourse. Educational discourse focuses on highlighting the social standard of ideological and political education and playing the social role, and emphasizes ideological guarantee and political maintenance of ideological and political education discourse. Educational discourse can not fully reveal the attention dimensions of individual survival and development, which lacks digging and research of cultural accumulation, cultural identification and cultural innovation of ideological and political education discourse.

3.3 Conflict and Integration: the Complexity of Rational Identification of Ideological and Political Education Discourse Culture Patterns

The interaction and fusion among global cultural discourse has resulted in the independent judgments, inclusive existence and conscious recognition of discourse, thus accelerating the rational generation of modern cultural discourse. However, on the one hand, due to the discourse features of traditional ideological and political education discourse, such as monosyllabic content, monotony of artistic discourse and lagging of discourse transmission, ideological and political education discourse embodies discourse aphasia and failure in the context of global cultural discourse. On the other hand, under the influence of diversified cultural discourse patterns, ideological and political education discourse shows multi-layered and wide-ranging cultural conflicts between dominant cultural discourse and diversified cultural discourse, central cultural discourse and marginal cultural 
discourse, mainstream cultural discourse and various sub-culture cultural discourse, dominant cultural discourse and autonomy cultural discourse, constructive cultural discourse and deconstructive cultural discourse.

\section{Conclusion}

\subsection{To Actively Form Cultural Orientations of Modernity of Ideological and Political Education Discourse}

It is necessary to actively construct the culture orientation cultivation system of ideological and political education discourse which includes the cognitive basis of discourse culture, historical identification of discourse culture, nature analysis of discourse culture, theoretical transformation of discourse culture and practice and innovation of discourse culture. Besides, it's necessary to enhance cultural self-confidence of ideological and political education discourse and safeguard cultural safety of ideological and political education discourse.

\subsection{To Rationally Promote Cultural Inheritance of Modernity of Ideological and Political Education Discourse}

It's necessary to be committed to formation of modern cultural inheritance mode of ideological and political education discourse. With the further development of social modernity and the deep manifestation of modern dimensions, it's obvious that traditional discourse culture inheritance mode such as text interpretation, infusion of cultural points and course examination can not reasonably connect with the new cultural inheritance objective and path of the educated people who live in the "era of reading" and, "video era". On the basis of that, we should be good at using modern media and means of communication, infuse outstanding culture with good historical inheritance and funny pictures and wonderful videos and other forms into the ideological and political education discourse practice, which means to enhance the cultural inheritance of ideological and political education discourse.

\subsection{To Scientifically Construct Cultural Context of of Modernity of Ideological and Political Education Discourse}

It's necessary to deeply grasp the contemporary situation of cultural context of ideological and political education discourse. Nowadays, under the strong trend of cultural globalization, cultural combination styles and integration styles are diversified and infiltrated into the cultural activities of the daily life of the educated people. Correspondingly, the cultural context of ideological and political education discourse changes from the static writing discourse expression to the dynamic picture discourse expression and visual discourse expression. Facing the turning point of modern cultural context, discourse reception demand of the educated needs to be fully considered. Meanwhile, with the help of specific cultural intelligence, cultural expression and cultural media, we should focus on improving the appeal and affinity of the audience in the context of ideological and political education discourse culture.

\section{References}

[1] Hui Huang. Discussion on the Chinese Culture Infiltration and Methods in English Teaching[J]. Dongyue Tribune (2008) No. 4.

[2] Essays of Marx and Engels. Vol. 9. Beijing: People’s Publishing House. 2009, p. 120. 